\title{
PREVALENCE OF BLOOD-BORNE VIRUSES AMONG IRANIAN DENTISTS: RESULTS OF A NATIONAL SURVEY
}

MOHAMMAD SADEGH AHMAD AKHOUNDI ${ }^{1,2}$, NAFISEH MOMENI ${ }^{1}$, MEHDI NOROUZI ${ }^{3}$, LEILA GHALICHI $^{4}$, AHMAD REZA SHAMSHIRI ${ }^{5}$, SEYED MOAYED ALAVIAN ${ }^{6}$, VAHDAT POORTAHMASEBI ${ }^{3}$, and SEYED MOHAMMAD JAZAYERI ${ }^{3}$

${ }^{1}$ Tehran University of Medical Sciences, Tehran, Iran

Dental Research Center, Dental Research Institute

${ }^{2}$ Tehran University of Medical Sciences, Tehran, Iran

Department of Orthodontics, Faculty of Dentistry

${ }^{3}$ Tehran University of Medical Sciences, Tehran, Iran

Department of Virology, School of Public Health, Hepatitis B Molecular Laboratory

${ }^{4}$ Iran University of Medical Sciences, Tehran, Iran

Department of Epidemiology and Biostatistics, Mental Health Research Center

${ }^{5}$ Tehran University of Medical Sciences, Tehran, Iran

Department of Epidemiology and Biostatistics, Dental Research Center

${ }^{6}$ Middle East Liver Diseases Center (MELD Centers), Tehran, Iran

Department of Molecular Hepatology

\begin{abstract}
Objectives: Health care workers, including dentists, are at the front line for acquiring blood-borne virus infections. This study aimed to investigate the prevalence of hepatitis B, hepatitis C and human immunodeficiency viruses among Iranian dentists. Material and Methods: The survey included 1628 dental health care workers who attended the 51st annual Congress of the Iranian Dental Association. Data on the risk of blood-borne virus transmission during health care and infection control practices were gathered from self-administered questionnaires. Sera were screened serologically by enzyme-linked immunosorbent assay (ELISA). The positive samples were examined by polymerase chain reaction (PRC) followed by direct sequencing. Results: Six $(0.36 \%)$ and $81(5.0 \%)$ were positive for hepatitis B surface antigen (HBsAg) and (anti-hepatitis B virus core antigen (anti$\mathrm{HBc}$ ), respectively. Only $1(0.061 \%)$ was positive for anti-hepatitis C virus (anti-HCV). No case was positive for anti-human immunodeficiency virus (anti-HIV). One case was diagnosed as being occult hepatitis B virus (HBV) infection. One thousand five hundred thirty-five $(94.3 \%$ ) of participants had received at least 1 dose of HBV vaccine. One thousand three hundred fifty-nine $(88.5 \%)$ contained hepatitis B surface antibody (anti-HBs) > $10 \mathrm{IU} / \mathrm{ml}$, of whom 55 (4.0\%) were anti-HBc positive, suggesting that they had been infected with $\mathrm{HBV}$ in the past. Anti-HBc positive cases had past histories of hepatitis, either their own or their spouses'. Individuals with inadequate anti-HBs levels $(<10 \mathrm{IU} / \mathrm{ml})$ were significantly more prevalent among anti-HBc positive cases $(\mathrm{p}<0.001)$. Conclusions: The prevalence of blood-borne viruses among dental HCWs found in this study was lower than past reports from Iranian dentists and general population. The implementation of HBV vaccination together with improvement in infection control procedures has reduced the potential for risk infection among Iranian dentists.
\end{abstract}

Key words:

Infection control, Blood-borne viruses, Dentists, Health care workers, Occult hepatitis B infection, HBV vaccine

This study was supported by Tehran University of Medical Sciences (Grant No. 132/2212).

Received: May 12, 2014. Accepted: November 12, 2014.

Corresponding author: S.M. Jazayeri, Tehran University of Medical Sciences, Department of Virology, School of Public Health, Hepatitis B Molecular Laboratory, PO Box 14155-6446, Tehran, Iran (e-mail: jazayerism@tums.ac.ir). 


\section{INTRODUCTION}

Health care workers (HCWs) are at the front line for acquiring blood-borne virus (BBV: hepatitis B virus (HBV), hepatitis $\mathrm{C}$ virus (HCV) and human immunodeficiency virus (HIV)) infections. Among the HCWs, dentists are the most highly exposed group and many dentists experience a needle stick or puncture of finger skin very often $[1,2,3]$. Due to the nature of invasive medical instruments used in dentistry, the transmission of blood-borne viruses in dental offices is a potential hazard to both patients and dental staff. Worldwide, dental health care workers experience higher chance of HBV infection than of other blood-borne viruses like HCV and HIV; and HBV incidences increase with years of clinical experience as a dentist [4,5]. Moreover, a higher prevalence of HBV infection especially among surgical specialties (oral and maxillofacial surgeons and periodontists) compared to the general population has been reported $[6,7]$.

Owing to the implementation of HBV vaccine in the immunization program for infants and high risk groups (including HCWs), HBV infection rates have been decreased dramatically. However, past (anti-hepatitis B virus core antigen (anti-HBc) positivity) or present (hepatitis B surface antigen ( $\mathrm{HBsAg}$ ) positivity) HBV infection rates in dentists are usually higher than in the general population, regardless of HBV endemicity in the area [8]. Hepatitis B surface antigen (HBsAg) prevalence among dentists has been reported to be $0.6 \%$ in Canada [9], 2.4\% in Malaysia [10] and $13 \%$ in Korea [11]. The rate of anti-HBc prevalence is $10.8 \%$ in Brazil [12], 9.6\% in Argentine [13], 7.8\% in the USA [4], $12 \%$ in Japan [14] and 7\% in Germany [15]. Therefore, dental care workers should be advised to receive a hepatitis $B$ vaccine and it should be confirmed if they have acquired immunity to HBV $[4,5,15]$.

Regarding other BBVs, lower risks of transmission between dental HCWs are associated with HCV including: $0.0 \%$ in Japan [14], $0.5 \%$ in Germany [15], 0.4$0.9 \%$ in Brazil [16,17], $0.33 \%$ in Israel [18], $0.4 \%$ in
Italy [19], 1.2\% in United Kingdom (UK) [20], 0.7-2\% in USA [4], and 3.3\% in Canada [9]. Finally, the prevalence for HIV has been considerably lower in dental settings: $0.02-0.3 \%$ (UK) [21] and 0.33\% (Canada) [9].

The aims of the present study were to investigate the seroprevalence and occupational factors and other associates of BBV sero-posivity among Iranian dentists.

\section{MATERIAL AND METHODS \\ Participants}

The study was a nonrandomized, cross-sectional survey of dental health care workers attending the 51st annual Congress of the Iranian Dental Association (Tehran, Iran) held on 10-13 May 2011. A total of 1628 participants were recruited. The inclusion criteria were: being involved in dental experience (regardless of job details), and willingness to give blood samples. For dental students, the duration of dental practice was excluded from the analysis. Informed consent was obtained from all the enrolled participants, and a questionnaire was used to collect data. Items of inquiry included gender, age, occupational information, details of using protective barriers and history of risk factors related to blood-borne transmission. The positive BBV cases were referred to Tehran Hepatitis Network for clinical following up. Due to the large amount of data, the detail of HBV vaccination status of participants has been published elsewhere [22].

\section{Serology}

Viral markers of hepatitis B virus were measured by enzyme-linked immunosorbent assay (ELISA) including $\mathrm{HBsAg}$, anti-HBs and anti-HBc (HBcAb 1 step, MBS. SRL. Medical Biological Service, Italy). Antibodies to HCV an HIV were detected by ELISA using Anti-HCV 3.0 ELISA Kit and Anti-HIV Plus ELISA Kit (MBS SRL Medical Biological Services, Italy).

All HBsAg, anti-HCV and anti-HIV reactive samples were rechecked by other ELISA kits from different companies. 


\section{DNA extraction, polymerase chain reaction (PCR) and DNA sequencing}

When the serum was positive for either HBsAg or anti$\mathrm{HBc}, \mathrm{HBV}$ DNA levels were analyzed using real-time PCR. Subsequently, surface standard PCR and sequencing for surface gene were carried out. Hepatitis B virus (HBV) DNA was extracted from a $200 \mu$ l of aliquot of serum using Qiagen Mini Blood Kit (Qiagen, Hilden, Germany) according to the manufacturer's instruction. At the final step, DNA was eluted using $100 \mu$ l of elution buffer, stored in $-20^{\circ} \mathrm{C}$. Real-time PCR was applied for HBV serodiscordant sera using Fast-diagnostics kits (Luxembourg) according to manufacturer's instructions. Polymerase chain reaction (PCR) was carried out in $100 \mu$ l of a mixture containing $5 \mu \mathrm{l}$ of the extracted DNA to amplify the complete surface gene using S1, S2, S6 and S7 primers as described previously [23]. Direct sequencing of surface gene was carried out (Genetic Analyzer ABI- 3130 DNA Sequencer, Fostercity, CA, USA) using 2 pmol of appropriate primers: S6C and S7D for surface gene. The electropherograms were examined visually using Chromas program. Sequences of surface gene were aligned using the BioEdit Package version 7.0.9.

\section{Data analysis}

The results on BBV status were compared between subjects on the basis of: demographic features, HBV vaccination status, BBV transmission risk factors, using routine protective tools. Finally, the study groups were compared according to the results of BBV infection into positive and negative groups and the variables were compared as a whole.

\section{Statistical study}

The descriptive statistics was calculated. Continuous variables were presented as means and standard deviations and compared using Student's t test. Categorical variables were demonstrated as numbers and percentages and compared with the Chi ${ }^{2}$ or Fisher's exact test. Ninetyfive percent confidence intervals for the point estimates were provided. $\mathrm{P}$ value less than 0.05 was considered significant. Data were analyzed with SPSS version 18.

\section{RESULTS}

The basic characteristics of dental health care workers are shown in Table 1. The mean age of participant was $40.4 \pm 11.1$ years (from 19 to 75 ). From the total of 1628 participants, $1070(65.7 \%)$ and $558(34.3 \%)$ were male and female, respectively. The mean duration for dental practice was $15.5 \pm 9.3$ years (from 0 to 55 years), with exception of dental students.

\section{Blood-borne viruses (BBV) prevalence}

Overall, among 1628 dental care workers, 7 (0.42\%) were positive for HBsAg (all were positive also for anti$\mathrm{HBc}$ ) and 81 (5.0\%) were anti-HBc positive. Only 1 person $(0.061 \%)$ was positive for anti-HCV. No case was positive for anti-HIV (Table 1).

Of 81 anti-HBc positive individuals, $66(81.4 \%)$ had a history of vaccination (Table 1); 55 (83.3\%) had protective levels of anti-HBs ( $\geq 10 \mathrm{IU} / \mathrm{ml})$, and $11(16.7 \%)$ had inadequate anti-HBs levels $(<10 \mathrm{IU} / \mathrm{ml})$. Nevertheless, $13(16.5 \%)$ of anti-HBc positive dentists did not receive vaccine, 7 had $\geq 10$ IU of anti-HBs and 6 had inadequate levels $(<10 \mathrm{IU} / \mathrm{ml})$ of whom 2 were positive for HBsAg (Table 1). A history of HBV vaccination was missing for 2 anti-HBc-positive individuals. More details of HBV vaccination are shown in Table 1.

Fifty-two serodiscordant cases had enough sera for further molecular studies. Real-time PCR was carried out on all these samples. One case was diagnosed as being occult HBV infection (HBsAg negative, HBV DNA positive with titer of $1950 \mathrm{copy} / \mathrm{ml}$ ). He was HBeAg negative, anti-HBe positive. In mutational analysis, no mutation was found over the entire surface protein (results not shown). Hepatitis B surface antigen positive cases had HBV DNA 
Table 1. Basic characteristics of dental participants

\begin{tabular}{|c|c|}
\hline Variable & $\begin{array}{l}\text { Participants } \\
(\mathrm{N}=1628)\end{array}$ \\
\hline 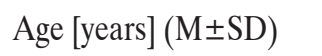 & $40.40 \pm 11.07$ \\
\hline \multicolumn{2}{|l|}{ Gender $[\mathrm{n}(\%)]$} \\
\hline male & $1070(65.72)$ \\
\hline female & $558(34.27)$ \\
\hline \multicolumn{2}{|l|}{ HBV vaccination [n (\%)] } \\
\hline no & $60(3.68)$ \\
\hline yes & $1535(94.28)$ \\
\hline unknown & $33(2.02)$ \\
\hline \multicolumn{2}{|l|}{ Marriage status [n (\%)] } \\
\hline single & $396(24.30)$ \\
\hline married & $1207(74.00)$ \\
\hline \multicolumn{2}{|l|}{ Anti-HBs status [n (\%)] } \\
\hline$<10 \mathrm{IU} / \mathrm{ml}$ & $176(11.46)$ \\
\hline$\geq 10 \mathrm{IU} / \mathrm{ml}$ & $1359(88.53)$ \\
\hline \multicolumn{2}{|l|}{$\mathrm{HBcAb}$ titer $[\mathrm{n}(\%)]$} \\
\hline negative & $1547(95.02)$ \\
\hline positive & $81(4.97)$ \\
\hline \multicolumn{2}{|l|}{ HBsAg $[n(\%)]$} \\
\hline negative & $1621(99.57)$ \\
\hline positive & $7(0.42)$ \\
\hline \multicolumn{2}{|l|}{ Anti-HCV Ab [n (\%)] } \\
\hline negative & $1627(99.94)$ \\
\hline positive & $1(0.06)$ \\
\hline \multicolumn{2}{|l|}{ Anti-HIV Ab [n (\%)] } \\
\hline negative & $1628(100)$ \\
\hline positive & $0(0.00)$ \\
\hline \multicolumn{2}{|c|}{ Anti-HBc/HBsAg state [n (\%)] } \\
\hline anti-HBc-/HBsAg- & $1547(95.03)$ \\
\hline anti-HBc-/HBsAg + & $0(0.00)$ \\
\hline anti-HBc+/HBsAg- & $74(4.54)$ \\
\hline anti-HBc+/HBsAg + & $7(0.43)$ \\
\hline
\end{tabular}

M - mean; SD - standard deviation; HBV - hepatitis B virus; antiHBs - hepatitis B surface antibody; $\mathrm{HBcAb}$ - hepatitis B core antibody; HBsAg - hepatitis B surface antigen; anti-HCV Ab - anti-hepatitis $\mathrm{C}$ virus antibodies; anti-HIV $\mathrm{Ab}$ - anti-human immunodeficiency virus; anti- $\mathrm{HBc}$ - anti-hepatitis B virus core antigen. levels (median $(\mathrm{Me})$ : $1.8 \times 10^{5}$ ranging between $1.3 \times 10^{4}$ and $3.44 \times 10^{5} \mathrm{copy} / \mathrm{ml}$ ). No other cases were positive by real-time PCR. Twelve cases were isolated anti-HBc. Twenty-six of cases showed adequate levels of anti-HBs in the absence of previous vaccination. Hence, they had a history of resolved HBV infection. Seven cases were positive for both anti-HBc and anti-HBs antibodies, suggesting a typical HBV resolved infection.

\section{Status of HBV vaccination}

From total vaccinated 1535 individuals, $176(11.5 \%)$ had levels of anti-HBs $<10 \mathrm{IU} / \mathrm{ml}$ and $1359(88.5 \%)$ had antiHBs $>10 \mathrm{IU} / \mathrm{ml}$, regardless of the number of doses and time after the last dose or time intervals between doses (Table 1) [22]. Among the latter group, 55 were anti-HBc positive with no apparent clinical history of HBV-related liver diseases, suggesting that they had been infected with HBV in the past. Thirty-three individuals attained adequate levels of anti-HBs in the absence of previous HBV vaccination (Table 1), indicating acquisition of previous infection at some time in the past, resulting in the natural immunity.

\section{Distribution of BBV among dental health care workers}

Seventy of $81(85.2 \%)$ anti-HBc-positive and all HBsAg positive $(100 \%)$ cases were general practitioners. None of general dental practitioners had evidence of HCV infection (Table 1). Seven of 119 (5.8\%, 95\% CI: 2.6-11.8\%) specialists, $1 / 37(2.7 \%, 95 \%$ CI: $0.5-13.6 \%)$ dental assistants and 3/155 dental students (1.9\%, 95\% CI: 0.7-5.5\%) were anti-HBc positive (results not shown). One of specialist group was positive for anti-HCV.

\section{Risk factors}

To determine possible risk factors for BBV acquisition, 1084/1592 (68.1\%) were reported to have at least 1 history of needle stick and other sharp-tool injuries (results not shown). This prevalence was higher, 
although not significantly, than for those who were negative for any BBV infection (76.2\% vs. $67.6 \%, \mathrm{p}=0.11$ ) (results not shown). Sixty-seven of 1605 (4.2\%) of cases had a history of sharp trauma, of whom only $1(1.5 \%)$ was positive for anti-HBc. Ninety of 1604 (5.6\%) of participants had a history of transfusion, of those $10(11.1 \%)$ were positive for anti-HBc (Table 2). The anti-HCV positive case had 2 episodes of needle-stick injury.

All HBsAg positive cases were general practitioners and of male gender and they were married. All showed antiHBs $<10 \mathrm{IU} / \mathrm{ml}$, however, they had been vaccinated. They have been working as dentists for at least 15 years. All had a positive history for needle stick injury. No other risk factor determinants for HBV infection were found.

\section{Protective barriers}

Regarding using routine protective tools as a whole, 1542 out of 1575 (97.9\%) were reported to use new disposables for every new patients. The frequencies of using such tools were lower for those who were positive for anti-HBc, but this association was not significant (97.5 vs. 97.8, $p=0.70$ ) (Table 2). However, the odds of previous or current HBV infection for dentists who regularly wore shield were higher than of those who used them irregularly or not at all.

\section{Anti-HBc positive vs. anti-HBc negative group comparison}

Finally, the 81 dentists with serological evidence of $\mathrm{HBV}$ infection (anti-HBc/HBsAg) were compared to the 1547 without either. In univariate analysis, the following variables had significant effects on being anti-HBc positive (Table 2). The mean age of anti-HBc positive group was higher than anti-HBc negative group $(\mathrm{p}<0.001)$. A majority of anti-HBc positive individuals were of male gender $(p=0.04 \%)$ (Table 2). A significant

Table 2. Demographic data, vaccination status and risk factors between anti-HBc positive dental participants vs. those negative for anti-HBc

\begin{tabular}{|c|c|c|c|}
\hline \multirow{2}{*}{ Variable } & \multicolumn{2}{|c|}{ Participants } & \multirow[b]{2}{*}{$\mathrm{p}$} \\
\hline & $\begin{array}{l}\text { anti- } \mathrm{HBc} \text { positive } \\
(\mathrm{N}=81)\end{array}$ & $\begin{array}{l}\text { anti-HBc negative } \\
\quad(\mathrm{N}=1547)\end{array}$ & \\
\hline Age [years] (M $\pm \mathrm{SD})$ & $46.8 \pm 12.2$ & $40.1 \pm 10.9$ & $<0.001$ \\
\hline Duration of dental practice [years] $(\mathrm{M} \pm \mathrm{SD})$ & $20.1 \pm 11.5$ & $15.2 \pm 9.1$ & 0.001 \\
\hline Gender (male) $[\mathrm{n}(\%)]$ & $62(76.5)$ & $1006(34.8)$ & 0.04 \\
\hline Marital status (being married) [n (\%)] & $67(83.7)$ & $1136(74.8)$ & 0.07 \\
\hline Vaccination $[\mathrm{n}(\%)]$ & $66(81.4)$ & $1468(96.9)$ & $<0.001$ \\
\hline Incomplete anti-HBV immunity [n (\%)] & $18(22.2)$ & $190(12.3)$ & 0.009 \\
\hline History of needle stick [n (\%)] & $60(75.9)$ & $1020(67.5)$ & 0.12 \\
\hline History of liver diseases [n (\%)] & $11(13.6)$ & $105(6.8)$ & 0.02 \\
\hline History of blood transfusion [n (\%)] & $10(12.5)$ & $80(5.2)$ & 0.01 \\
\hline Using gloves for each patient [n (\%)] & $78(97.5)$ & $1469(95.0)$ & 0.70 \\
\hline Using mask for each patient [n (\%)] & $78(96.3)$ & $1444(96.0)$ & 1.00 \\
\hline Using glasses for each patient [n $(\%)]$ & $54(68.3)$ & $1128(95.4)$ & 0.09 \\
\hline Using shield for each patient [n $(\%)]$ & $19(25.0)$ & $547(37.9)$ & 0.02 \\
\hline
\end{tabular}

Abbreviations as in Table 1. 
proportion of anti-HBc positive individuals were married $(p=0.07)$. Also, the duration of dental practice was longer in the anti-HBc positive than the anti-HBc negative group $(20.1 \pm 11.5$ vs. $15.2 \pm 9.1, \mathrm{p}<0.001)$ (Table 2$)$. Anti$\mathrm{HBc}$ positive cases had past histories of hepatitis either in their own or her/his spouse (for both $\mathrm{p}<0.001$ ). Sixtysix $(83.5 \%)$ of anti-HBc individuals were vaccinated. Vaccination history of these 2 groups showed that anti-HBs levels below $10 \mathrm{IU} / \mathrm{ml}$ were more prevalent among antiHBc positive cases $(\mathrm{p}<0.06)$ (Table 2$)$.

\section{DISCUSSION}

Due to the fact that dental health proceedures involve aerosol-forming equipment and sharp devices [24,25], there has long been a great concern about transmission of blood-borne pathogens in dentistry [26,27]. The transmission of blood-borne viruses in dental offices is a potential hazard to patients [28]; and as dentists and dental staff during their routine practice use sharp instruments in an environment contaminated with saliva and blood, they appear particularly prone to these blood-borne infections. Despite of no evidence for non-parenteral (enteral/respiratory) transmission of $\mathrm{BBV}$, there have been controversies about the oral transmission efficiency for BBVs [2931], and thus, virus transmission via saliva may be possible, probably due to the contamination of saliva with blood. Although the probability of infections due to contaminated needle sticks are lower for HCV and HIV compared to HBV [32,33], the rate of contracting HBV infection through HBV-contaminated needles is as high as $12 \%$ [34] to $60 \%$ (in unvaccinated individuals) $[14,35]$.

The risk of occupational blood-borne infections by dental practitioners is well recognized in the case of HBV. Numerous reports are accessible indicating that before the availability of vaccine against HBV in the 80 s, the seroprevalence of $\mathrm{HBV}$ was higher among dentists than in the general population $[36,37]$. However, after the implementation of Expanded Program on Immunization (EPI) on HBV endorsed by World Health Organization (WHO) together with $\mathrm{HBV}$ vaccination national programs among dentists, recent data show that this prevalence is equal or even lower in dentists than that of general population $[12,38]$. In Iran, it is estimated that over $35 \%$ of the general population have been exposed to HBV and approximately $2.5 \%$ are chronic carriers [39]. In the present study, only $0.36 \%$ and $4.5 \%$ of individuals were positive for HBsAg and anti-HBc, respectively. On the other hand, previous studies on Iranian dental health care workers showed a prevalence of $1.1 \%$ and $7-14.7 \%$ for $\mathrm{HBsAg}$ and anti-HBc positivity, respectively [40-42]. However, sample sizes in those studies were small as well as they were encumbered with sample selection bias, because the participants were recruited from single provinces instead of the general dentistry community. The present study confirms that application of HBV vaccine together with protective tools has decreased the overall $\mathrm{HBV}$ infection in this high-risk group.

WHO has declared that dentists are at greater risk of acquiring $\mathrm{HCV}$. Despite this, a number of studies have shown that the prevalence of $\mathrm{HCV}$ infection in this group is similar (1.2\%) [19] or even lower (0.0\%) [14] than that of the general population [43]. Interestingly, only 1 out of $1628(0.06 \%)$ of dental care workers in our study was HCV-positive. Similarly, 1 Iranian study on dental workers showed a prevalence of $0 \%$ for HCV [40].

Moreover, in a Brazilian study, the seroprevalence of HCV was $0.9 \%$ among a calculated sample of 1302 dentists tested, which was lower than the $1.42 \%$ prevalence of $\mathrm{HCV}$ reported for the general population in the same area [16]. Collectively, other similar results for HCV prevalence in dental HCWs [14] suggest that dentists have a lower risk of HCV infection caused by occupational accidents than expected by the WHO [43]. As the serum viral concentration and exposure dose are critical factors for the transmission of blood-borne pathogens, the low prevalence of HCV among dentists may be explained by the relatively 
low infectivity of HCV found in saliva or by the small volume of blood inoculation involved in dental accidents [44]. Although the relative prevalence of immunodeficiency virus is low among the dental HCWs (being 0.02-0.33\% in Western surveys $[9,21])$, none of cases in our study was positive for HIV. This finding underscores the usefulness of implementation of education programs and stronger control measures, including dissemination of the knowledge about the proper use of disinfection and sterilization systems.

In the present survey, $176(11.5 \%)$ of participants did not have protective levels of anti-HBs antibody and their levels of anti-HBs were low. Thirty-three individuals attained adequate levels of anti-HBs in the absence of previous $\mathrm{HBV}$ vaccination, indicating acquisition of previous infection at some time in the past, resulting in the natural immunity. Nevertheless, 62 (6.2\%) of those with adequate anti-HBs levels were anti-HBc positive with no apparent clinical history of HBV-related liver diseases, suggesting that they had been transiently and apparently infected with HBV in the past. Twelve cases were isolated antiHBc. Finally, 1 case had occult HBV infection. Though we did not find any mutation over the surface protein, as we shown previously, low expression of $\mathrm{HBs} \mathrm{Ag}$, concomitant presence of wild type and mutant and other possibilities could be the reason for undetectability of $\mathrm{HBsAg}$ in this case [45-47]. Thus, despite these serodiscordant groups were negative for HBV DNA (excluding the latter case), they should be carefully monitored for further EPP (exposure prone procedures) in their practice.

Regarding the risk factors for acquisition of BBV, despite some subjects had histories of trauma with sharp injury, transfusion, etc., they did not show significant associations with these with BBV infection in our investigation. However, in all circumstances, those risks were higher in subjects with positive past or current HBV infection.

Among the Iranian dentists, the odds of being HBsAg/ anti-HBc positive did not differ significantly according to the consistent use of gloves or eye glasses (97.5 vs. 97.8, $\mathrm{p}=0.70$ ), however, odds of such markers were higher for dentists who regularly wore shield than of those who used them irregularly or did not use them at all.

The present study has some limitations. Cross-sectional studies are performed either over a short period or at a single point in time. Thus, causal relationship should not be considered for associations identified in these studies. Also, due to the fact that the participants' responses were self-reported, generalizations must be considered with caution. Moreover, the probability of information bias could be involved, because some volunteers may practice habits or activities different from their self-reported behavior. Therefore, our findings may not represent the whole population of Iranian dentists. Our sample size, however, the largest among Iranian dental worker surveys studies, has shed important light on the prevalence of BBV between Iranian dentists.

\section{CONCLUSIONS}

In conclusion, despite that prevalence of HBV among dental HCWs found in this study was lower than in other reports from Iran and also lower than that in the Iranian general population, due to the invasive nature of dental practice, permanent vigilance and educational programs addressing BBV infection among dentists are necessary. Guidelines need to be developed to ensure that the entire dental team is vaccinated against HBV. To reduce risk of HCV and HIV infections (as no vaccine is available yet for both), educational interventions are required to improve compliance with universal precautions, the use of barriers, puncture-proof containers for sharps disposal, and post-exposure protocols.

\section{REFERENCES}

1. Rybacki M, Piekarska A, Wiszniewska M, Walusiak-Skorupa J. Hepatitis B and C infection: Is it a problem in Polish healthcare workers? Int J Occup Med Environ Health. 2013; 26(3):430-9, http://dx.doi.org/10.2478/s13382-013-0088-0. 
2. Sofola OO, Savage KO. Assessment of the compliance of $\mathrm{Ni}$ gerian dentists with infection control: A preliminary study. Infect Control Hosp Epidemiol. 2003 Oct;24(10):737-40, http://dx.doi.org/10.1086/502122.

3. Albertoni F, Ippolito G, Petrosillo N, Sommella L, di Nardo V, Ricci C, et al. Needlestick injury in hospital personnel: A multicenter survey from central Italy. Infect Control Hosp Epidemiol. 1992 Sep;13(9):540-4, http://dx.doi. org/10.2307/30147182.

4. Thomas DL, Gruninger SE, Siew C, Joy ED, Quinn TC. Occupational risk of hepatitis $\mathrm{C}$ infections among general dentists and oral surgeons in North America. Am J Med. 1996 Jan;100(1):41-5, http://dx.doi.org/10.1016/ S0002-9343(96)90009-1.

5. Reingold AL, Kane MA, Hightower AW. Failure of gloves and other protective devices to prevent transmission of hepatitis B virus to oral surgeons. JAMA. 1988 May 6;259(17):2558-60, http://dx.doi.org/10.1001/jama.19 88.03720170034029 .

6. Gillcrist JA. Hepatitis viruses A, B, C, D, E and G: Implications for dental personnel. J Am Dent Assoc. 1999;130(4): 509-20, http://dx.doi.org/10.14219/jada.archive.1999.0245.

7. Martins AM, Barreto SM. [Hepatitis B vaccination among dentists surgeons]. Rev Saude Publica. 2003 Jun;37(3): 333-8. Portuguese.

8. McCarthy GM, Britton JE. A survey of final-year dental, medical and nursing students: Occupational injuries and infection control. J Can Dent Assoc. 2000;66(10):561.

9. Shah SM, Merchant AT, Dosman JA. Percutaneous injuries among dental professionals in Washington State. BMC Public Health. 2006;6:269, http://dx.doi.org/10.1186/14712458-6-269.

10. Vadivale M, Tan TC, Ong CN. Seroprevalence of hepatitis B infection among dental professionals. Singapore Med J. 1992 Aug;33(4):367-9.

11. Song KB, Choi KS, Lang WP, Jacobson JJ. Hepatitis B prevalence and infection control among dental health care workers in a community in South Korea. J Public
Health Dent. 1999 Winter;59(1):39-43, http://dx.doi. org/10.1111/j.1752-7325.1999.tb03233.x.

12. Batista SM, Andreasi MS, Borges AM, Lindenberg AS, Silva AL, Fernandes TD, et al. Seropositivity for hepatitis B virus, vaccination coverage, and vaccine response in dentists from Campo Grande, Mato Grosso do Sul, Brazil. Mem Inst Oswaldo Cruz. 2006 May; 101(3):263-7, http://dx.doi.org/10.1590/S0074-02762006000 300006 .

13. Echeverria RF, Curciarello JO, Basualdo JA, Gomez JC, Corallini O, Perez CA, et al. [Prevalence of hepatitis B virus infection in dentists of District I of the province of Buenos Aires]. Acta Gastroenterol Latinoam. 1988;18(4):253-62. Spanish.

14. Nagao Y, Matsuoka H, Kawaguchi T, Ide T, Sata M. HBV and $\mathrm{HCV}$ infection in Japanese dental care workers. Int J Mol Med. 2008 Jun;21(6):791-9, http://dx.doi. org/10.3892/ijmm.21.6.791.

15. Ammon A, Reichart PA, Pauli G, Petersen LR. Hepatitis B and $\mathrm{C}$ among Berlin dental personnel: Incidence, risk factors, and effectiveness of barrier prevention measures. Epidemiol Infect. 2000 Oct;125(2):407-13, http://dx.doi. org/10.1017/S0950268899004537.

16. Resende VL, Abreu MH, Paiva SM, Teixeira R, Pordeus IA. Factors associated with seroprevalence of hepatitis C among dentists at a large Brazilian city. Virol J. 2009 Dec 23;6:228, http://dx.doi.org/10.1186/1743-422X-6-228.

17. Takahama AJ, Tatsch F, Tannus G, Lopes MA. Hepatitis C: Incidence and knowledge among Brazilian dentists. Community Dent Health. 2005 Sep;22(3):184-7.

18. Ashkenazi M, Fisher N, Levin L, Littner MM. Seroepidemiology of hepatitis $\mathrm{C}$ antibodies among dentists and their self-reported use of infection control measures. Community Dent Health. 2009 Jun;26(2):99-103.

19. Brambilla E, Cagetti MG, Fadini L, Tarsitani G, Strohmenger L. [Epidemiologic survey of medical and non-medical personnel in a public dental clinic]. Ann Ig. 2005 MarApr;17(2):155-62. Italian. 
20. Lodi G, Porter SR, Teo CG, Scully C. Prevalence of HCV infection in health care workers of a UK dental hospital. $\mathrm{Br}$ Dent J. 1997 Nov 8;183(9):329-32.

21. Gore SM, Felix DH, Bird AG, Wray D. Occupational risk and precautions related to HIV infection among dentists in the Lothian region of Scotland. J Infect. 1994 Mar;28(2):209-22.

22. Momeni N, Akhoundi MSA, Alavian SM, Shamshiri AR, Norouzi M, Mahboobi N, et al. HBV vaccination status and response to hepatitis $\mathrm{B}$ vaccine among Iranian dentists, correlation with risk factors and preventive measures. Hepat Mon. 2014 Dec 27;15(1):e20014, http://dx.doi.org/10.5812/ hepatmon.20014.

23. Jazayeri SM, Basuni AA, Sran N, Gish R, Cooksley G, Locarnini S, et al. HBV core sequence: Definition of genotype-specific variability and correlation with geographical origin. J Viral Hepat. 2004;11(6):488-501, http://dx.doi. org/10.1111/j.1365-2893.2004.00534.x.

24. Prospero E, Savini S, Annino I. Microbial aerosol contamination of dental healthcare workers' faces and other surfaces in dental practice. Infect Control Hosp Epidemiol. 2003 Feb;24(2):139-41, http://dx.doi.org/10.1086/502172.

25. Al-Khatib IA, Ishtayeh M, Barghouty H, Akkawi B. Dentists' perceptions of occupational hazards and preventive measures in East Jerusalem. East Mediterr Health J. 2006 Jan-Mar;12(1-2):153-60.

26. Feldman RE, Schiff ER. Hepatitis in dental professionals. JAMA. 1975 Jun 23;232(12):1228-30, http://dx.doi. org/10.1001/jama.1975.03250120016014.

27. Smith JL, Maynard JE, Berquist KR, Doto IL, Webster HM, Sheller MJ. From the center for disease control: Comparative risk of hepatitis B among physicians and dentists. J Infect Dis. 1976 Jun;133(6):705-6, http://dx.doi.org/10.1093/ infdis/133.6.705.

28. Mahboobi N, Agha-Hosseini F, Safari S, Lavanchy D, Alavian SM. Hepatitis B virus infection in dentistry: A forgotten topic. J Viral Hepat. 2010;17(5):307-16, http://dx.doi. org/10.1111/j.1365-2893.2010.01284.x.
29. Angelillo IF, Villari P, D’Errico MM, Grasso GM, Ricciardi G, Pavia M. Dentists and AIDS: A survey of knowledge, attitudes, and behavior in Italy. J Public Health Dent. 1994 Summer;54(3):145-52, http://dx.doi. org/10.1111/j.1752-7325.1994.tb01206.x.

30. Castro Ferreiro M, Hermida Prieto M, Diz Dios P. [Sporadic transmission of hepatitis $\mathrm{C}$ in dental practice]. Med Clin (Barc). 2004;123(7):271-5. Spanish.

31. Belyakov IM, Berzofsky JA. Immunobiology of mucosal HIV infection and the basis for development of a new generation of mucosal AIDS vaccines. Immunity. 2004 Mar;20(3):247-53.

32. Sodeyama T, Kiyosawa K, Urushihara A, Matsumoto A, Tanaka E, Furuta $S$, et al. Detection of hepatitis $C$ virus markers and hepatitis $\mathrm{C}$ virus genomic-RNA after needlestick accidents. Arch Intern Med. 1993 Jul 12;153(13):156572, http://dx.doi.org/10.1001/archinte.1993.00410130081008.

33. Mitsui T, Iwano K, Masuko K, Yamazaki C, Okamoto H, Tsuda F, et al. Hepatitis $C$ virus infection in medical personnel after needlestick accident. Hepatology. 1992 Nov; 16(5):1109-14, http://dx.doi.org/10.1002/hep.1840160502.

34. Werner BG, Grady GF. Accidental hepatitis-B-surface-antigen-positive inoculations. Use of e antigen to estimate infectivity. Ann Intern Med. 1982 Sep;97(3):367-9, http://dx.doi. org/10.7326/0003-4819-97-3-367.

35. U.S. National Heart and Lung Institute Collaborative Study Group and Phoenix Laboratories Division, Bureau of Epidemiology, Center for Disease Control. Relation of e antigen to infectivity of hBsAg-positive inoculations among medical personnel. Lancet. 1976 Sep 4;1(7984):492-4.

36. Cleveland JL, Siew C, Lockwood SA, Gruninger SE, Gooch BF, Shapiro CN. Hepatitis B vaccination and infection among U.S. dentists, 1983-1992. J Am Dent Assoc. 1996;127(9):1385-90, http://dx.doi.org/10.14219/jada. archive.1996.0457.

37. Alavian SM, Izadi M, Zare AA, Lankarani MM, Assari S, Vardi MM. Survey of the level of anti-HBs antibody titer in vaccinated Iranian general dentists. Spec 
Care Dentist. 2008 Nov-Dec;28(6):265-70, http://dx.doi. org/10.1111/j.1754-4505.2008.00052.x.

38. Bellissimo-Rodrigues WT, Machado AA, Bellissimo-Rodrigues F, Nascimento MP, Figueiredo JF. Prevalence of hepatitis $\mathrm{B}$ and $\mathrm{C}$ among Brazilian dentists. Infect Control Hosp Epidemiol. 2006 Aug;27(8):887-8, http://dx.doi. org/10.1086/506407.

39. Alavian SM, Hajarizadeh B, Ahmadzad-Asl M, Kabir A, Bagheri-Lankarani K. Hepatitis B virus infection in Iran: A systematic review. Hepat Mon. 2008;8(4):14.

40. Behnaz MA, Behnaz F, Mohammadzadeh M. The prevalence of hepatitis $\mathrm{C}$ infection among the dentist of Yazd and assessment of their knowledge about hepatitis. J Dent (Tehran). 2004;17(1):55-9.

41. Kamangar E, Atarpor M, Saneimighadam E, Zohour AR, Nayeb Aghayee SM. Prevalence of serologic markers of hepatitis $\mathrm{B}$ and $\mathrm{C}$ and risk factors among dentists and physicians in Kerman, Iran. J Kermn Univ Med Sci. 2003;10(4):240-5.

42. Baharvand M, Iramloo Z. Survey of anti-HBs titers in vaccinated dental students of Shahid Beheshti University of Medical Sciences in 2002. Beheshti Univ Dent J. 2004;21(Special Issue):653-60.
43. World Health Organization. Hepatitis C. Fact sheet number 164, revised October 2000 [cited 2009 Mar]. Available from: http://www.who.int/mediacentre/factssheets/fs164len.

44. Gerberding JL. Incidence and prevalence of human immunodeficiency virus, hepatitis $B$ virus, hepatitis $C$ virus, and cytomegalovirus among health care personnel at risk for blood exposure: Final report from a longitudinal study. J Infect Dis. 1994 Dec;170(6):1410-7, http://dx.doi.org/ 10.1093/infdis/170.6.1410.

45. Alavian SM, Carman WF, Jazayeri SM. HBsAg variants: Diagnostic-escape and diagnostic dilemma. J Clin Virol. 2013 Jul;57(3):201-8, http://dx.doi.org/10.1016/j.jcv. 2012.04.027.

46. Alavian SM, Miri SM, Hollinger FB, Jazayeri SM. Occult hepatitis $\mathrm{B}(\mathrm{OBH})$ in clinical settings. Hepat Mon. 2012;12(8):e6126, http://dx.doi.org/10.5812/hepatmon.6126.

47. Shahmoradi S, Yahyapour Y, Mahmoodi M, Alavian SM, Fazeli Z, Jazayeri SM. High prevalence of occult hepatitis B virus infection in children born to $\mathrm{HBs} A g$-positive mothers despite prophylaxis with hepatitis B vaccination and HBIG. J Hepatol. 2012 Sep;57(3):515-21, http://dx.doi. org/10.1016/j.jhep.2012.04.021.

This work is available in Open Access model and licensed under a Creative Commons Attribution-NonCommercial 3.0 Poland License - http://creativecommons.org/ licenses/by-nc/3.0/pl/deed.en. 